Equilibrium : Jurnal Pendidikan

Vol. X. Issu 1. Januari-April 2022

\title{
Relasi Kuasa Dokter Kepada Pasien di Klinik Kecantikan Naavagreen Natural Skincare Kotabaru Yoyakarta
}

\author{
Juli Natalia Silalahi \\ Dosen Prodi Sosiologi FISIP UPR \\ Email : julinataliasilalahi12@fisip.upr.ac.id
}

\begin{abstract}
Beautiful construction designed by various entities, including Naavagreen Natural Skincare Kotabaru, Yogyakarta. Naavagreen offers patients that is natural beauty, quality, cheap and reliable for all customers. This condition makes the public trust in Naavagreen skincare (Paransih, 2017). Naavagreen patients are willing to put aside their salary, time for treatment at Naavagreen, and even let their skin and face be treated by Naavagreen to get a beautiful concept as constructed by Naavagreen. Patient trust is based on Naavagreen designed like a legitimate hospital room, this condition further strengthens Naavagreen patients for treatment. The patient has entrusted his body to Naavagreen, this condition further strengthens that the patient's body is increasingly subdued through the beauty clinic. This study uses a qualitative research method with a case study approach. This research was conducted in May 2017. The research location was taken at the Naavagreen Natural Skincare Beauty Clinic in Kotabaru, Yogyakarta. There were four informants who were interviewed. The concept of analysis uses Michael Foucault's thinking about the birth of clinic as well as power and knowledge. The results of this study are that the power relationship between doctors and patients is dominated by doctors who have legitimacy in subduing the patient's body (skin and face) to follow the recommended treatment. Patients are dominated to follow it, even patients become a means of spreading power over the knowledge of Doctors and Naavagreen institutions (beauty specialists) about the beautiful concept offered by Naavagreen. Patients are disciplined by Doctors or Naavagreen. Naavagreen is able to differentiate between naturally beautiful, clean people from people who do not meet the criteria for beauty for Naavagreen. The beautiful construction of Naavagreen's version is getting more complete and more accommodating people's expectations about beauty that must be fulfilled by everyone.
\end{abstract}

Keywords : Power Relation; Doctor; Patient; Naavagreen; Beauty Clinic

Abstrak. Konstruksi cantik didesain oleh berbagai entitas, termasuk Naavagreen Natural Skincare Kotabaru, Yogyakarta. Naavagreen menawarkan kepada pasien yaitu cantik alami, berkualitas, murah dan terpercaya bagi semua pelanggan. Kondisi ini membuat besarnya kepercayaan dari masyarakat terhadap Naavagreen skincare (Paransih, 2017). Pasien Naavagreen rela menyisihkan gaji, waktu untuk berobat atau perawatan di Naavagreen, bahkan membiarkan kulit dan wajah mereka diobati oleh Naavagreen untuk mendapatkan konsep cantik seperti yang dikonstruksi oleh Naavagreen. Kepercayaan pasien didasarkan oleh Naavagreen didesain layaknya ruang dalam rumah sakit yang terlegitimasi, kondisi ini semakin memperkuat pasien Naavagreen untuk berobat. Pasien sudah mempercayakan tubuhnya kepada Naavagreen, kondisi ini semakin memperkuat bahwa tubuh pasien semakin ditundukkan melalui klinik kecantikan. Penelitian ini menggunakan metode penelitian kualitatif dengan pendekatan studi kasus. Penelitian ini dilaksanakan pada bulan Mei Tahun 2017. Lokasi penelitian diambil pada Klinik Kecantikan Naavagreen natural skincare di Kotabaru, Yogyakarta. Informan yang diwawancarai sebanyak empat orang. Adapun konsep analisis menggunakan pemikiran Michael Foucault tentang the birth of clinic serta kekuasan dan pengetahuan. Adapun hasil penelitian ini yaitu relasi kuasa Dokter dan pasien didominasi oleh Dokter yang memiliki keabsahan dalam menundukkan tubuh (kulit dan wajah) pasien untuk mengikuti perobatan yang dianjurkan. Pasien terdominasi untuk mengikutinya, bahkan pasien menjadi sarana penyebaran kekuasaan atas pengetahuan Dokter dan lembaga Naavagreen (spesialisasi kecantikan) tentang konsep cantik yang ditawarkan oleh Naavagreen. Pasien didisplinkan oleh Dokter atau Naavagreen. Naavagreen mampu memberikan pembedaan orang cantik alami, bersih dengan orang yang tidak sesuai kriteria cantik bagi Naavagreen. Konstruksi cantik versi Naavagreen semakin lengkap dan semakin mengakomodir harapan masyarakat tentang kecantikan yang harus dipenuhi setiap orang.

Kata Kunci : Relasi Kuasa; Dokter; Pasien; Naavagreen; Michel Foucault 


\section{PENDAHULUAN}

Makna cantik di era saat ini menjadi isu yang menegangkan. Berbagai entitas memberikan pemaknaan cantik yang berbeda-beda dengan tujuan mendapatkan pengakuan dari objek yang disasar. Salah satu entitas itu adalah klinik kecantikan yang kian marak saat ini. Seperti klinik kecantikan Naavagreen. Naavagreen menampilkan makna cantik yang alami dengan menggunakan kemajuan teknologi. Naavagreen hadir bermula di Yogyakarta pada tanggal 11 Agustus 2012, yaitu menjadi pusat perawatan kecantikan kulit. Naavagreen juga menawarkan biaya yang lebih murah, berkualitas, yang prima dan terpercaya bagi semua pasien serta pelayanan yang ramah. Selain itu, pelayanan dokter yang profesional. Klinik kecantikan ini menampilkan ruangan seperti layaknya legal formal klinik untuk memberikan keabsahan bagi pasiennya bahwa Naavagreen sebagai klinik yang kompeten secara ilmiah bagi pasien. Pada klinik ini terdapat ruangan seperti ruang konsultasi dengan dokter, apotek, ruangan administrasi, riwayat berobat dan jadwal terstruktur dalam pengobatan. Semua sudah didesain layaknya klinik umum kesehatan lainnya atau bahkan seperti layaknya rumah sakit.

Kontruksi cantik semakin diperkuat dengan narasi yang meyakinkan para pasien. Seperti yang dikatakan oleh Sumapradja, dkk (2014) bahwa konsep cantik ideal seperti tubuh yang ramping, rambut hitam berkilau, dan kulit wajah yang putih, bersih. Untuk itu, perempuan di era saat ini sangat memerlukan kecantikan. Kondisi ini disebabkan oleh kuatnya konstruksi masyarakat dalam mendorong para perempuan mengikuti kemauan masyarakat. Seperti pendapat wijayanti, (2020) bahwa di Indonesia sendiri, memiliki kulit yang cerah dan merona, bertubuh langsing dengan rambut hitam lurus dan panjang merupakan simbol kecantikan yang paling banyak diakui orang-orang. Oleh karena itu, kondisi ini menjadi peluang bagi berbagai entititas, termasuk klinik kecantikan Naavagreen.

Klinik Kecantikan Naavagreen menawarkan cantik alami, berkualitas, dan harga terjangkau. Kondisi ini banyak membuat masyarakat khususnya mahasiswa-mahasiswa, para pekerja tertarik menggunakan produk kecantikan Naavagreen. Bahkan, masyarakat sudah menganggarkan sebagian dari uang mereka untuk membeli produk tersebut. Masyarakat memahami bahwa cantik seperti konstruksi dari klinik kecantikan Naavagreen. Senada dengan itu, salah satu dokter di Klinik Kecantikan Naavagreen Kotabaru, Yogyakarta mengatakan bahwa cantik itu adalah kebutuhan, seperti kebutuhan menggunakan sikat gigi. Begitu pula pendapat dari pasien Naavagreen bahwa cantik itu menghindari ejekan sosial, tuntutan kerja, untuk mendapatkan pasangan hidup, dan para pasien pun sudah percaya dengan Naavagreen karena sudah mengakomodir harapan mereka tentang cantik.

Pasien klinik kecantikan naavagreen rela menyisihkan gaji, waktu, tubuh, wajah mereka untuk mendapatkan konsep cantik seperti yang dikonstruksi oleh Naavagreen. Bahkan, mereka rela mengantri begitu lama untuk konsultasi dengan dokter kecantikan di klinik tersebut. Setiap pasien yang sudah terdaftar di klinik kecantikan Naavagreen, maka riwayat pasien tersebut akan terekam layaknya di pasien umum di rumah sakit umum. Pasien dalam proses konsultasi dengan dokter hanya bisa mengikuti yang menjadi saran dari dokter tersebut. Dalam pengambilan keputusan memang pasien diberikan kebebasan, tetapi Dokter klinik tersebut memberikan sugesti bagi pasien untuk mengikuti saran obat atau tindakan bagi pengobatan wajah atau kulit bagi pasien. Bahkan pasien mengganggap bahwa untuk cantik, perlu merawat diri bagaikan service motor. Pasien mempercayakan wajah dan tubuh mereka kepada klinik kecantikan Naavagreen.

Klinik kecantikan Naavagreen mampu memberikan kepercayaan kepada pasien. Seperti dalam buku The Birth of The Clinics yang ditulis oleh Foucault (1965) dalam Rokhayati (2015) bahwa dokter memiliki kekuasaan dalam vonis pengetahuan yang dimilikinya kepada pasien. Seorang dokter dengan kapasitas pengetahuan yang dimilikinya mempunyai otoritas penuh untuk mengatakan seseorang itu sehat atau sakit. Otoritarianisme dokter ini diperteguh dengan derap laju modernitas. Klinik-klinik kesehatan, puskesmas, dan rumah sakit didirikan untuk manampung kuasa pengetahuan dokter. Akibatnya, dengan kuasa pengetahuan itu, masyarakat menjadi sangat tergantung pada dokter dalam menentukan sakit atau sehat sekaligus untuk mencari kesembuhan atas sakit yang ia derita. 
Masyarakat rela membayar mahal untuk mendapatkan kesembuhan versi dokter. Realitas ini menempatkan profesi kedokteran mempunyai nilai yang penting di masyarakat. Dan, karena posisi politis itu, seorang dokter berusaha untuk tetap mempertahankan kuasanya. (Rokhayati, 2015).

Oleh karena itu, peran dokter sangat dominan, apalagi klinik Kecantikan didesain layaknya ruang dalam rumah sakit yang terlegitimasi, kondisi ini semakin memperkuat pasien Naavagreen untuk berobat. Pasien sudah mempercayakan tubuhnya kepada Naavagreen, kondisi ini semakin memperkuat bahwa tubuh pasien semakin ditundukkan melalui klinik kecantikan.

Klinik bagi Foucault merupakan realitas yang menyimpan banyak misteri bagi terselenggaranya suatu praktek kekuasaan. Rumah sakit dan kedokteran klinis dinilai Foucault sebagai metode terbaik untuk merawat pasien dan melatih para dokter muda. Inilah yang disebut Foucault dengan Klinik. Atas nama pengetahuan, membedah mayat bukan lagi hal baru dan tabu. Karena melibatkan mayat, maka gagasan tentang kematian mengalami perubahan. Kematian bukan lagi ketiadaan hidup, tetapi puncak kehidupan atau kematian awal dari sebuah kehidupan baru karena menurut Foucault pembedahan mayat memberi ilmu kedokteran kesempatan untuk menundukkan seluruh tubuh pada tatapan mata ilmiah. (Syahputra, $2010: 5$ ).

Kontrol atas tubuh juga dituliskannya menjadi bagian integral dalam pendisiplinan dengan program-program yang diawasi melalui pencatatan. Rumah peristirahatan memberlakukan pasien atas dasar pengendalian diri dengan cara yang kontinu tanpa henti melalui penyadaran atas kesalahan (Foucault dalam Rokhayati, 2015). Saat Kurzweil menuliskan deskripsi pemikiran Foucault dalam konteks kelahiran klinik, ia menyebutkan perlakuan para dokter terhadap pasien yang diidentifikasi melalui pendekatan yang objektivis. Pengamatan yang menjadi pendekatan penting dalam dunia medik di satu sisi memperlakukan manusia sebagai sekedar objek amatan. Mula-mula pasien diamati kemudian menjadi subjek kurikulum ilmu kedokteran yang terstruktur dalam rangka pengembangan keilmuan. Lewat ini Foucault menunjukkan secara simultan klinik atau rumah sakit menjadi akses profesi bagi pelajar-pelajar medis dengan diberlakukannya surat ijin bagi pegawai kesehatan, tenaga profesional dan dokter (Kurzweil dalam Rokhayati, 2015).

Disebutkan pula secara bersamaan, situasi di atas berimplikasi terhadap akses untuk mendekati tubuh terutama saat perlakuan autopsi dilakukan. Bedah mayat akhirnya dilegalkan akibat akses otoritas dokter yang berimplikasi terhadap dimulainya suatu penyelidikan baru atas penyakit dan pencegahannya bagi pendisiplinan masyarakat. Pada dasarnya, otoritas dokter yang memiliki wewenang atas kontrol tubuh menjadikan rumah sakit dan para dokter memiliki posisi istimewa dengan membangun perangkat episteme yang mendukung keberlangsungan posisinya. (Rokhayati, 2015).

Dalam masyarakat modern, semua tempat berlangsungnya kekuasaan juga menjadi tempat pembentukan pengetahuan tentang kegilaan, seksualitas, produksi. Fenomena kegilaan menjadi lahan subur perkembangan psikiatri, psikologi, dan kedokteran. Seks merupakan sumber berkembangnya psikoanalisa, psikologi, kedokteran, kriminologi, etika, bahkan teologi. Produksi mendorong perkembangan ilmu ekonomi, sosiologi, psikologi. Demikian sebaliknya, semua pengetahuan memungkinkan dan menjamin beroperasinya kekuasaan. Kehendak untuk mengetahui menjadi proses dominasi terhadap objek-objek dan terhadap manusia. Pengetahuan adalah cara bagaimana kekuasaan memaksakan diri kepada subjek tanpa memberi kesan bahwa ia datang dari subjek tertentu, karena kriteria keilmiahan seakan-akan mandiri terhadap subjek. Padahal klaim ini merupakan bagian dari strategi kekuasaan. (Haryatmoko, $2016: 17$ ).

Kekuasaan menghasilkan pengetahuan, kekuasaan dan pengetahuan saling terkait, tidak ada hubungan kekuasaan tanpa pembentukan yang terkait dengan bidang pengetahuan, dan tidak ada pengetahuan yang tidak mengandaikan serta tidak membentuk sekaligus hubungan kekuasaan. Anatomi politik menunjukkan bahwa teknik kekuasaan, produksi dan pengetahuan lahir dari sumber yang sama. Memang anatomi politik itu tidak menciptakan pengetahuan, tetapi geneologi. Dengan metode geneologi ditunjukkan bahwa kebenaran yang mengambil bentuk objektivitas ilmu itu hanya ilusi. Metode yang sama memperlihatkan bahwa kehendak untuk tahu menjadi proses dominasi 
terhadap manusia. Setiap pengetahuan terkait dengan objek kekuasaan, yaitu orang gila, kriminal, anak remaja, orang sakit, buruh. Kaitannya terletak pada kemampuan pengetahuan mendefenisikan realitas objek tersebut. Dengan mendefenisikan realitas, akibatnya pengetahuan mengubah konstelasi sosial. (Haryatmoko, 2016 : 17-18).

\section{METODE PENELITIAN}

Penelitian ini menggunakan metode penelitian kualitatif dengan pendekatan studi kasus. Adapun studi kasus yang diambil yaitu studi kasus instrinsik. (Creswell, 2015: x) Studi kasus intrinsik yaitu fokusnya adalah kasus itu sendiri karena dianggap unik atau tidak biasa. Fokus pada kasus keunikan Naavagreen sebagai klinik kecantikan. Naavagreen mampu memberikan pelayanan kecantikan layaknya ruang kesehatan secara general seperti di Rumah Sakit, Puskesmas, atau klinik. Lokasi penelitian diambil pada Klinik Kecantikan Naavagreen natural skincare di Kotabaru, Yogyakarta. Produk Naavagreen menyesuaikan dengan kulit didaerah tropis, seperti Indonesia. Saat ini Naavagreen sudah memiliki cabang dibeberapa wilayah di Indonesia. Adapun mayoritas pengguna Naavagreen yaitu mahasiswa dan karyawan.

Penelitian ini melakukan teknik pengumpulan data melalui beberapa tahapan yaitu, pertama, observasi. Mengumpulkan catatan lapangan dengan melakukan pengamatan ke Naavagreen sebagai partisipan aktif (pasien) dan pengamat. Kedua, wawancara. Wawancara dilakukan secara tidak terstruktur, yaitu wawancara terbuka dengan merekam hasil wawancara dan menuliskan hasil wawancara tersebut dalam laporan. Pemilihan informan dengan Purposive Sampling. Adapun total informan yang diwawancarai yaitu 4 orang, yaitu 3 orang pasien Naavagreen dam 1 orang Dokter di Naavagreen. Ketiga. Dokumen. Peneliti menulis catatan lapangan selama penelitian berlangsung, selain itu juga menganalisis dokumen terkait dengan naavagreen, pasien, dokter, dan pemikiranpemikiran Micahel Foucault sebagai pisau analisis. Adapun teknik keabsahan data dilakukan melalui triangulasi. Peneliti melakukan tanya jawab dengan teman sejawat terkait topik Naavagreen dalam pemikiran Micahel Foucault. Selain itu, peneliti juga melakukan klarifikasi bias peneliti.

\section{HASIL PENELITIAN DAN PEMBAHASAN}

\section{Hasil Penelitian}

\section{a. Profil Naavagreen Natural Skincare}

Di Yogyakarta pada tanggal 11 Agustus 2012 telah berdiri pusat perawatan kecantikan kulit yang bernama naavagreen Natural Skincare. Semua proses perawatan dan produknya menggunakan bahan-bahan alami/natural. Keuntungan lain yang dapat diperoleh di naavagreen adalah selain tentunya dengan biaya yang lebih murah, juga kualitas produk yang prima, dan pelayanan yang ramah serta pelayanan dokter yang profesional. (Naavagreen Natural Skincare, 2021). Hal ini sejalan dengan visi dan misi dari Naavagreen Natural Skincare yaitu visi, menjadi pusat pelayanan perawatan kecantikan kulit dan wajah secara alami/natural, berkualitas dan murah, yang prima dan terpercaya bagi semua. Adapun misi, yaitu mengembangkan keterampilan dan profesionalisme karyawan, serta memberikan pelayanan perawatan yang alami / natural, berkualitas, murah dan terpercaya bagi semua pelanggan.

\section{b. Politik Ruang di Naavagreen Natural Skincare}

Ruangan di Naavagreen Natural Skincare dilegitimasi layaknya ruang khusus yang ahli dibidang kesehatan kulit. Naavagreen Skincare menampilkan berbagai ruang yang seirama dengan rumah sakit, Puskesmas, Klinik yang mengobati penyakit umum. Klinik Naavagreen ini juga harus mengikuti prosedur seperti di Rumah Sakit, Puskemas, Klinik. Seperti halnya pasien harus mendaftarkan diri, lalu tidak bisa membeli produk kecantikan ini sembarangan, tetapi harus melalui prosedur layaknya 
berobat di lembaga kesehatan formal, yaitu mendaftarkan diri, kemudian konsultasi dengan dokter lalu bisa menebus obat. Obat yang ditawarkan juga sesuai kuasa dari dokter, sedangkan pasien hanya bisa mengikuti, begitupun halnya ketika dokter menganjurkan untuk melakukan tindakan atas penyakit pada kulit, wajah. Maka, pasien tersugesti untuk mengikuti anjuran dokter tersebut.

Dalam hal berobat ke Klinik Naavagreen tersebut pun harus membawa kartu berobat, jika tidak maka sulit untuk diproses pengobatan, konsultasi, ataupun hanya ingin membeli produk (obat). Adapun masing-masing pasien sudah memiliki rekam medik di Klinik Naavagreen, setiap proses berobat akan didiagnosa jenis penyakit kulit, wajah yang diderita pasien. Berikut tata letak ruang di Naavagreen Natural Skincare :

Gambar 1.1 Ruang Konsultasi Antara Pasien dan Dokter

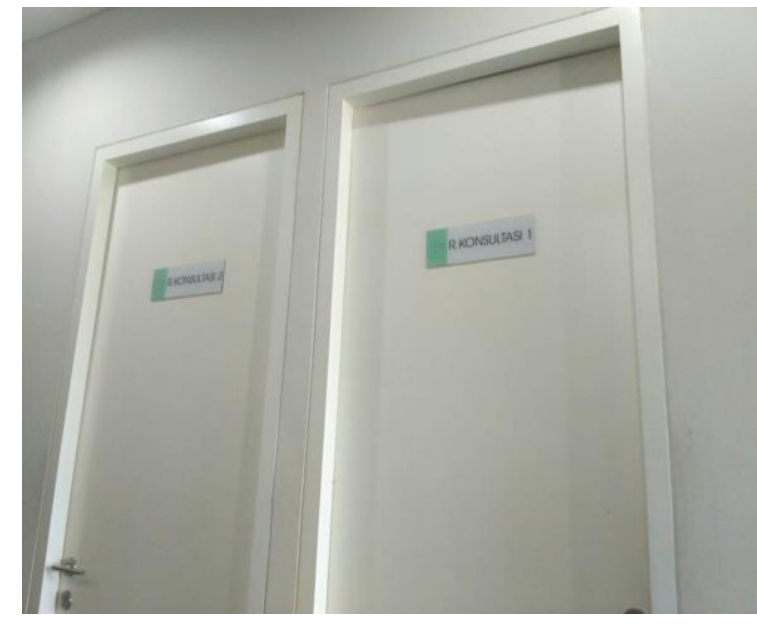

(Sumber : Dokumentasi Peneliti)

Gambar 1.2 Ruang Pendaftaran

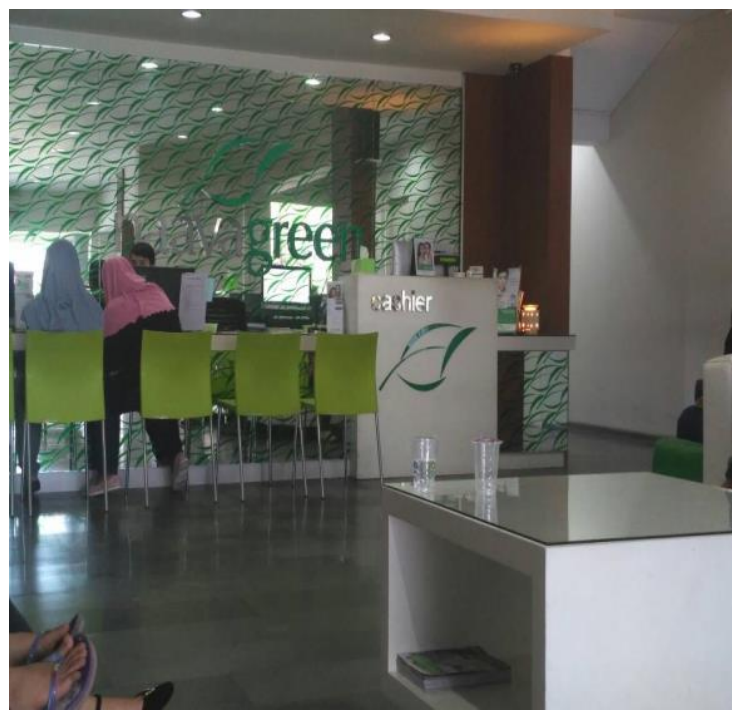

(Sumber : Dokumentasi peneliti) 
Gambar 1.3 Wawancara bersama Dokter di Klinik Naavagreen Kotabaru, Yogyakarta

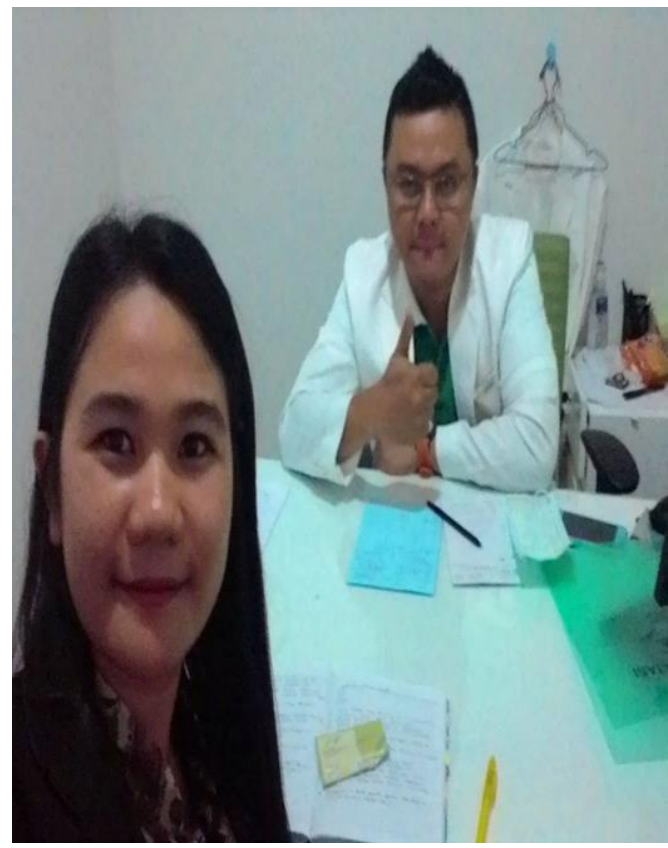

(Sumber : Dokumentasi peneliti)

Gambar 1.4 Klinik Kecantikan Naavagreen Natural Skincare di Kotabaru, Yogyakarta

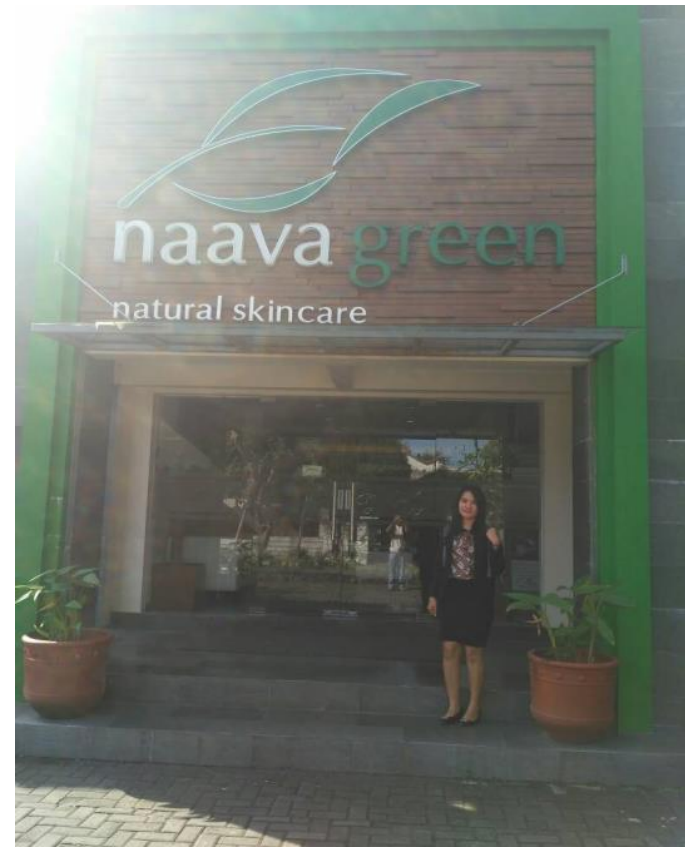

(Sumber : Dokumentasi Peneliti)

Adapun ruangan yang tampil di Naavagreen memang dilegitimasi seperti klinik, rumah sakit, atau puskesmas pada umumnya (klinik kecantikan didesain sama klinik umum). Bentuk ruangan juga 
menuju ke legitimasi bahwa ruangan ini layak secara ilmiah mengobati penyakit kulit, wajah secara ilmiah pula. Prosedur untuk berobat pun harus melalui catatan berobat (riwayat berobat) dan memperlukan kartu berobat, jika tidak ada makan sulit untuk diproses berobat, bahkan secara berkala pun pasien tidak bisa sesuka hati untuk berobat, sebab dalam berkala waktu diwajibkan untuk konsultasi ke dokter sebelum membeli produk (obat). Selain itu, naavagreen juga memiliki apotek seperti desain klinik umum. Bahkan, pasien pun tidak bisa sesuka hati untuk memesan obat bagi dirinya, semuanya harus sesuai dosis obat yang diberikan dokter. Legitimasi ruangan ini merupakan bagian politik ruang dalam memberikan kepercayaan pasien kepada Naavagreen secara relasi kuasa pantas dan layak sebagai klinik pada umumnya yang mampu mengobati spesial penyakit kulit, wajah (kesehatan kecantikan).

\section{Pembahasan}

Naavagreen skincare telah lama dipercaya oleh pasien, khususnya bagi pekerja dan mahasiswa, hal itu terlihat dari keramaian pasien didominsasi oleh mahasiswa dan pekerja. Kondisi itu dikarenakan, harga jasa dan produk di Naavagreen murah dan sesuai kantong mahasiswa dan para pekerja khususnya karyawan. Para pasien pun merasa aman berobat di Naavagreen, hal itu disebabkan kepercayaan yang tumbuh atas adanya dokter untuk berkonsultasi, dan proses berobat pun tidak sembarangan. Adapun konstruksi cantik dari Naavagreen memperkuat pasien semakin percaya, seperti pendapat pasien atas nama ibu Siska : "percaya pada Naavgreen, sudah modern, jika ada yang alami kenapa tidak". Narasi ini menunjukkan bahwa wacana kecantikan dari Naavagreen sudah mendominasi pasien, adapun konstruksi kecantikan Naavagreen yaitu menampilkan cantik alami.

Konstruksi cantik yang diwacanakan oleh Naavagreen mampu menguasai pasien. Kekuasaan dan pengetahuan adalah saling memiliki keterkaitan. Bagi Foucault (Haryatmoko, 2016 : 15) bahwa kekuasaan lebih digambarkan dalam tatanan disiplin yang dihubungkan dalam sejumlah jaringan. Disiplin tidak dapat diidentikkan dengan institusi atau aparat, ia adalah suatu tipe kekuasaan, suatu modalitas untuk menjalankan kekuasaan, yang terdiri dari keseluruhan sarana, teknik, prosedur, tingkat-tingkat penerapan, sasaran-sasaran, ia merupakan fisik atau anatomi kekuasaan, suatu teknologi. Dan ia dapat dijamin oleh institusi-institusi yang terspesialisasi seperti penjara, sekolah, rumah sakit).

Naavagreen pun mendesain tipe kekuasaan dalam bentuk sarana, teknik, prosedur seperti mendesain konstruksi cantik alami dengan bahan-bahan alami, menggunakan teknik warna hijau sebagai sumber alami, adapun tingkat penerapan berobat didesain berbeda-beda setiap pasien, dengan jenjang terstruktur dalam proses pengobatan. Kondisi seperti ini menuntun persepsi pasien tentang Naavagreen menjadi dipercaya. Konstruksi legitimasi sebagai klinik kecantikan yang kompeten mampu mengobati tubuh yang berpenyakit sehingga harus disembuhkan di klinik kecantikan Naavagreen. Konstruksi cantik klinik Naavagreen mampu menjaga keharmonisan dalam hubungan sosial, seperti pendapat informan Ibu Siska, yaitu : "Cantik itu bersih, menghindari ejekan sosial, dan tuntutan kerja". Diperkuat lagi dengan pendapat Ibu Susi, yaitu "cantik itu tuntutan kerja, pertemanan, pasangan hidup, merawat diri bagaikan service motor, sudah modern maka menggunakan Naavagreen" Adapun Konstruksi cantik sudah terlegitimasi dalam konsep para pasien Naavagreen. Mengapa hal itu bisa terjadi ? tentu dengan meminjam analisis Foucault bahwa rumah sakit sebagai penjamin yang handal dalam spesialisasi penyakit tubuh tertentu, dalam hal ini kulit dan wajah. Klinik kecantikan sebagai lembaga penjamin orang-orang handal yaitu Dokter, Apoteker dalam mengobati tubuh pasien yang sakit. Dokter memiliki legitimasi dalam memberikan vonis atas pengetahuan yang dimilikinya kepada pasien. Seorang dokter dengan kapasitas pengetahuan yang dimilikinya mempunyai otoritas penuh untuk menghakimi seseorang itu sehat atau sakit. Dokter Naavagreen pun mengonstruksi wacana kecantikan kepada pasien, dengan pernyataan sebagai berikut, "Klinik kecantikan didesain sama klinik umum, cantik itu seperti kebutuhan "Sikat gigi", jadi 
perawatan harus konsultasi dokter dan perawatan dahulu dengan bahan alami, namun didukung modernitas, wacana kecantikan jadi rasional." Pernyataan Dokter memberi legitimasi bagi pasien Naavagreen tentang perlunya cantik dan Naavagreen dapat memberikan kecantikan itu.

Klinik kecantikan memproduksi kekuasaan dan pengetahuan bagi pasien. Wacana kecantikan alami, berkualitas dan murah, yang prima dan terpercaya menjadi dasar Naavagreen memperluas tipe kekuasaannya. Naavagreen juga menjadi lembaga penjamin spesialisasi masalah kecantikan kulit dan wajah. Naavagreen dengan tipe kekuasaannya mampu memberikan legitimasi bagi pasien untuk berobat dan menyerahkan tubuhnya di obati oleh Naavagreen. Pasien semakin terdisiplinkan akan wacana kecantikan yang secara kontinu diproduksi oleh Naavagreen. Tubuh pasien menjadi lahan praktik eksperimen bagi Naavagreen. Naavagreen mampu memberikan pembedaan orang cantik alami, bersih dengan orang yang tidak sesuai kriteria cantik bagi Naavagreen. Bahkan, pasien Naavagreen sendiri sebagai sarana penyebar kekuasaan Naavagreen dalam memberikan rekomendasi cantik alami kepada teman sejawat, atau masyarakat. Konstruksi cantik versi Naavagreen semakin lengkap dan semakin mengakomodir harapan masyarakat tentang kecantikan.

Relasi kuasa dokter, Naavagreen ke pasien sangat mendominasi. Bahkan, pasien sudah menyisihkan sebagai uangnya untuk berobat di Naavagreen agar cantik alami seperti konstruksi Naavagreen dan masyarakat. Berobat di Naavagreen seperti investasi, bagaikan service motor. Kecantikan seperti konstruksi Naavagreen dapat memberikan kepercayaan lebih bagi si pasien dalam menjalani hubungan sosial, seperti mendapatkan pasangan, dihormati, dianggap ada di masyarakat, diterima dalam pertemanan, bahkan tuntutan kerja.

\section{KESIMPULAN}

Konstruksi cantik pada masa saat ini diperankan oleh beberapa entitas, termasuk klinik kecantikan, seperti Naavagreen Natural Skincare. Naavagreen menawarkan cantik alami, harga murah, biaya yang lebih murah, juga kualitas produk yang prima, dan pelayanan yang ramah serta pelayanan dokter yang profesional. Klinik kecantikan ini menampilkan ruangan seperti layaknya legal formal klinik untuk memberikan keabsahan bagi pasiennya bahwa Naavagreen sebagai klinik yang kompeten secara ilmiah bagi pasien. Pada klinik ini terdapat ruangan seperti ruang konsultasi dengan dokter, apotek, ruangan administrasi, riwayat berobat dan jadwal terstruktur dalam pengobatan. Semua sudah didesain layaknya klinik umum kesehatan lainnya atau bahkan seperti layaknya rumah sakit.

Klinik kecantikan memproduksi kekuasaan dan pengetahuan bagi pasien. Wacana kecantikan alami, berkualitas dan murah, prima dan terpercaya menjadi dasar Naavagreen memperluas tipe kekuasaannya. Naavagreen juga menjadi lembaga penjamin spesialisasi masalah kecantikan kulit dan wajah. Naavagreen dengan tipe kekuasaannya mampu memberikan legitimasi bagi pasien untuk berobat dan menyerahkan tubuhnya di obati oleh Naavagreen. Pasien semakin terdisiplinkan akan wacana kecantikan yang secara kontinu diproduksi oleh Naavagreen. Tubuh pasien menjadi lahan praktik eksperimen bagi Naavagreen. Naavagreen mampu memberikan pembedaan orang cantik alami, bersih dengan orang yang tidak sesuai kriteria cantik bagi Naavagreen. Bahkan, pasien Naavagreen sendiri sebagai sarana penyebar kekuasaan Naavagreen dalam memberikan rekomendasi cantik alami kepada teman sejawat, atau masyarakat. Konstruksi cantik versi Naavagreen semakin lengkap dan semakin mengakomodir harapan masyarakat tentang kecantikan. 


\section{DAFTAR PUSTAKA}

Creswell, John W. Penelitian Kualitatif \& Desain Riset Memilih diantara Lima Pendekatan (Edisi ke 3). Editor : Saifuddin Zuhri Qudsy, alih bahasa Ahmad Lintang Lazuardi, dkk. Yogyakarta : Pustaka Pelajar

Naavagreen. 2021. https://naavagreen.com/, diakses tanggal 28 Oktober 2021

Paransih, 2017. Pengaruh Citra Merek dan Kualitas Persepsian Terhadap Kepuasan dan Loyalitas Pelanggan Produk Naavagreen Skincare. Fakultas Ekonomi dan Bisnis Universitas Muhammadiyah Yogyakarta

Rokhayati, 2015. The Birth of The Clinics. http://blog.unnes.ac.id/dwirokhayati11/?p=6, diakses tanggal 17 Oktober 2021

Sumapradja, Chaerunnisa, dan Purwanto. 2014. Perilaku Mahasiswi Yogyakarta Dalam Mempercantik Wajah Melalui Klinik Kecantikan Yogyakarta University Student Behavior In Beautifying Face Throught Skincare. Tesis : UGM

Wijayanti, Sekar Arum. 2019. Analisis Pengaruh Perceived Service Quality dan Perceived Service Environment Terhadap Repurchase Intentions Yang Dimediasi Oleh Emotional Satisfaction (Studi Empiris Pada Konsumen Natasha Skin Care). Skripsi. Surakarta : Fakultas Ekonomi dan Bisnis Universitas Muhammadiyah Surakarta, http://eprints.ums.ac.id/76017/3/BAB\%20l.pdf, diakses tanggal 19 Oktober 2021

Wijayanti. 2020. Interpretasi Makna Kecantikan Pada Generasi Z. Jakarta : Universitas Persada Indonesia Indonesia Y.A.I

Hardiyanta, P. Sunu. 2016. Michael Foucault Disiplin Tubuh Bengkel Individu Modern. Yogyakarta : LKiS

Haryatmoko. 2016. Membongkar Rezim Kepastian. Yogyakarta : PT Kanisius 